\title{
THE SOCIAL AND FCOLOGICAL CORRELATES OF BANKRUPTCY DURING THE FARM FISCAL CRISIS, 1970-1987
}

\author{
Dr. John P. Smith \\ Clemson University
}

Mid-American Review of Sociology, 1987, Vol. XII, No. 1:35-54

For the last two decades, social scientists have accepted the premise that farm modernization resulted in larger, technologically sophisticated, and capital intensive farming units. In addition, it was a foregone conclusion that modernization led to fewer farm units. Several historians (Danbom, 1979; Shover, 1976; Fite, 1984) have described the historical origins of the process of farm modernization. A classic analysis of the structural and ideological change in American agriculture was presented by Rohrer and Douglas (1969) in The Agrarian Transition: Dualism and Change. This work generated a rethinking of the centrality and persistence of Agrarian ideology (Flinn and Johnson, 1974; Buttel and Flinn, 1975).

While the general thesis of an agrarian transition is widely accepted, questions remain about the pace or rate of the transition. Some historians have viewed this transition in epochal terms; the transition is likened to an "agrarian twilight," a slow fade. Other historians and social commentators have noted an uneven, nonlinear path for farm modernization and agricultural development in general. Some events like a technological breakthrough or a fiscal crisis can hasten the rate of modernization in the agricultural sector (Campbell, et al., 1984). Agricultural growth or decline, then, can be viewed in stages, and the factors that influence each stage can be studied.

Despite the torrent of press releases about increased farm income and government transfer payments, after 1981 it became apparent that the farm sector and rural communities were facing dire straits. The "fiscal crisis" of the early 1980's actually emerged slowly after 1978. It was an institutional crisis that involved the farm sector and agribusiness. It was not a simple problem of low cash flow for a select group of poor managers as it has been viewed by economists and management specialists. To understand the impact of the fiscal crisis, one needs to conceive of farming as a family business and an occupation that is fostered and nurtured by the parent generation, community and the state. When a farmer leaves farming, it is far more complex than in prior years because 
of the social and economic linkages to family, community and government agencies.

This article focuses upon the role of the fiscal crisis in the "agricultural transition." The thesis developed is that the fiscal crisis emerged in the late 1970's, and that it was followed by "rural immiseration" - a deteriorating social and economic condition for rural areas. Heffernan and Heffernan (1986) note that the individual suffering from farm stress continues to suffer stress after the loss of the farm. This is because the disengagement or "exit" from farming is far more complex than in prior years due to the structure of social and economic linkages to family, community, and government agencies. Communities suffer the misery of business closure. Families suffer from the effects of dislocation, a misery based upon the loss of friends, neighbors, and a valued way of life. Data to support this thesis are drawn from federal bankruptcy court records. The implications for the agrarian transition are discussed in the conclusion.

\section{THE FARMING CAREER}

In the early days of the "farm crisis," the course of the crisis was clearly attributed to poor management practices and overextension in credit. In short, farmers had made business mistakes. But these mistakes had been based on somewhat contradictory advice. Farm unit growth advocates among agricultural economists had urged farm operators to "leverage" their assets and equity to expand their farming unit. ${ }^{1}$ Other farm management experts cautioned farm operators that the cost of credit had been rising steadily since 1975 (Hottel and Barry, 1978), and they warned that a pattern of pay-back on farm expansion could not be guaranteed (Melichar, 1984). But farmers were not always making decisions as businessmen, but rather as family members.

Families make the decision to expand the farming unit. The decision may include economic factors, but it is of ten predicated upon family survival and the anticipated transfer of a viable farm unit to the next generation. In the era of farm expansion, opinions were sought from a variety of sources outside the family, including farm credit services and skilled professionals. The slow process of information gathering and decision making also involved the seeking of social opinion and reinforcement from friends and neighbors. Most of ten, sage advice and expert opinion indicated conditions were safe for growth. In brief, major decisions such as farm expansion took place within a social matrix of family support and community interaction.
Based upon such information and social support between 1978 and 1982, about one-quarter of farm operators increased the size of their operation. Figures vary from state to state on how many farm operators purchased land as a growth strategy and how many opted to cash rent land. United States Department of Agriculture figures show about 60 percent of the land on a typical commercial farm was owned and 40 percent of the land was leased (USDA, 1985). Figures from North Dakota developed from farm families in financial trouble indicated these farm operators averaged 53 percent of land owned and 47 percent rented/leased (Smith et al., 1984). There is no clear formula about how much land ought to be owned or leased. However, those farm operators that leveraged their land to buy additional ground found themselves at risk in a short time. They had made bad business decisions, and they, their families, and local communities would face the consequences.

One can observe the social implications of the decisions to expand when farming is viewed not as a business, but as an occupation that one gradually enters, going through a series of steps (Wright, 1943). Older works by agricultural economists, rural sociologists, and adult educators have focused on this "agricultural ladder." Arnold (1957) and Cof fman (1979) noted the problems of capital accumulation for young farmers who lacked family support. Ahalt and Murray (1956) and Martinson (1970) wrote of the external community and educational supports needed by young farmers in the process of becoming a farm owner-operator. More recently the level of family commitment to the beginning farmer has been noted by Salamon (1985), Wilkenning (1981), and Smith and Cole (1981). The key point is this. Farming is an occupation that one enters gradually. There are social stages involved as one becomes a farmer, and passage from one social stage to another requires family support and social institutional acceptance (see Coughenour and Kowalski, 1977). It looks like a business from an economists' point of view. But the career socialization stages are still present. Within this conceptualization of a farming career, the social and economic implications can be more fully understood. If the decision for farm unit expansion was made, it was probably a decision resulting from consultation within the family, with credit sources, and possibly with other skilled professionals. It also involved the social opinion and reinforcement of friends and neighbors. In brief, major decisions such as farm expansion, the acquisition of expensive technology, or the inter-generational transfer of the farm took place within a matrix of familial and social support and interaction. 
With a personal failure in farming, like a personal failure in other endeavors, the family, friends, and community might be a socially supportive bulwark against feelings of personal inadequacy and depression. But this network of support may weaken when one or more failures are experienced in a community in a short time frame. When farm families cease farming there are external business and institutional impacts on the community. Few farm families may leave their home county (Heffernan and Heffernan, 1986); however, their consumption practices are altered because of low paying replacement jobs or unemployment. Also their access to credit is severely limited if they filed for bankruptcy or left by foreclosure with no recoverable assets. For local banks and businesses, debt recovery and future credit are out of the question. And, of course, farming as a career option is limited without access to operating and equipment loans.

\section{THE FISCAL CRISIS IN FARMING}

The fiscal crisis of farming is attributed to high credit costs, low commodity prices, flaccid export demand, and high interest rates. The costs of credit began rising in 1975. After 1979, the federal sources of credit for farm entry and operating loans (Farmers Home Administration, Federal Land Bank, Production Credit Associations) permitted their interest rates to float at or near the rates offered by commercial banks. A system of commodity "target prices" and loans that had been established during the Carter administration were deemphasized in the 1980's, and were replaced by the PIK program in 1983. This was initiated as a solution to the problems of a growing surplus and chronic over-production. To further complicate matters, land prices continued to escalate until about 1983. Given the movement of these elements of the fiscal problems of farmers, precise dating of the most recent agricultural crisis is not easy. ${ }^{2}$

Recent survey results from several states indicated that between six and 18 percent of farms had debt/asset ratios of .7 or above. (Hammig, 1986:85). The farmers at risk had these average characteristics. Farm operators were 43.5 years of age, and their spouses were 39.9 years old. They had 1.9 children still at home, and they had been in farming for almost 21 years (Smith, et al., 1984). These farmers were neither beginning farmers, nor farmers at the end of their careers. Rather, they were farm operators at mid-career who had taken the risks of farm unit expansion. The reasons for risk-taking may be diverse. But it is strongly suspected that many farm families expanded with the intention of bringing a

\section{Social Correlates of the Farm Crisis}

young family member into the operation, and thus developing a unit large enough so that production capacity could support two families in partnership.

\section{Exiting the Fiscal Crisis}

In the Frontier era, a farm operator had few economic linkages. If financial problems arose, a farm family simply moved to the western frontier. As Shover (1965) noted, even during the Depression, many farmers merely walked away from unprofitable agricultural operations. But others went through the process of foreclosure (Alston, 1983), a process which became an organizing point for protests. ${ }^{3}$

In the 1980's, the process of farm exit is more complex because of a web of economic, legal, and government relations. If the farm operator is small and not liable for much debt, he or she can leave farming by simple migration. Foreclosure on land or equipment is initiated on the local county level by lenders after a pattern of debt default. However, in most cases, exiting farmers must go through foreclosure which has become more complicated in recent times. For example, an injunction issued by a federal court prohibited FmHA from using foreclosure, and from withholding operating loans and loans for household expenses (Coleman $v$. Block, 1984). Conveyance of land back to original owners or lenders has also complicated foreclosure proceedings. But conveyance is not popular because farm operators lose the equity in their land, and many farmers now seek to renegotiate loans with banks at lower interest rates.

Historically, farm bankruptcy laws were enacted from time to time in various states. Congress passed several general bankruptcy acts in the 19th century, only to repeal the laws later. In 1898, Congress passed a bankruptcy act that remained until 1978. States provided variable asset exemption levels and time procedures (Shepard, 1984). The Bankruptcy Act provided debt relief for workingmen and individuals who owned businesses (Straight Bankruptcy-Chapter 7). But these required either total asset transfer or debt elimination. A Chapter 13 bankruptcy gave court protection while debts were restructured and repaid. Reorganization for both is overseen by a court appointed trustee. In 1979 a new code was passed to permit protection of businesses that wanted to reorganize with court supervision (Chapter 11). Finally in response to farm problems, Congress passed the Family Farm Bankruptcy Act of 1986 (Synar, 1986).

There was an increase in bankruptcies after the passage of the 1979 Bankruptcy Code (Shepard, 1984:419). Many farm 
operations filed for protection under Chapter 11 of that code, but as Synar (1986) notes: "Chapter 11 has proven to be needlessly complicated, unduly time-consuming, too expensive and, in most farm cases, it is simply unworkable. Further, creditors have the ability to vote down Chapter 11 reorganization places proposed by farmers."

Under Chapter 12 of the 1986 Act, farmers are required to file a reorganization plan within 90 days of a bankruptcy protection. The plan must reflect how all disposable income for three to five years will be paid to insured creditors (e.g., local seed dealers, utility companies, etc.). Second, the plan must reflect how the payment of secured debts will be accomplished relative to the collateral on the debt. Here the creditor can receive the full negotiated value of the obligation across an extended period of time. Also farmers must be willing to sell of $\mathrm{f}$ portions of property to reduce their debt load. Finally, a trustee is appointed to supervise the payments, investigate fraud, and manage the farm if mismanagement is judged by the court. ${ }^{4}$ The Chapter 12 legislation was written to last for seven years, terminating in 1993 if it is not renewed.

Economists had mixed views of bankruptcy in general and Chapter 12 in particular. Webb (1983) argued that creditors have nothing to gain from forcing bankruptcy because of the legal and tax costs that follow a bankruptcy. Shepard (1984:426-7) emphasized the positive aspects of bankruptcy as a rational strategy for debtors to maximize wealth. Still others maintained that the long-term effects of lenient bankruptcy laws are unclear at best. But increased filings of bankruptcy are predicted in the future, and "dead beats" will impose greater externality on good credit risks (Dye, 1986:425).

\section{Problems of Bankruptcy}

Within the agrarian transition, it is conceivable that there were several time spans when farm modernization charged forward and then hung back. In short, there was uneven development. We wish to examine the effect of the present farm fiscal crisis on farm bankruptcy. The drive for growth and modernization motivated farm families to take risks. The erratic commodity prices of the 1970's followed by government subsidies led to large fluctuations in net farm income. This, in turn, led to default on loan payments, and the exit from farming for many. ${ }^{5}$

Reliable state records of the farm decline are difficult to locate. The Crop and Livestock Reporting Service estimates the number of farms per state each year, but gives no regional or subregional breakdown within each state. The Census of Agriculture reports county farm numbers from which estimates can be constructed in normal situations. However, the fiscal crisis in farming removed the "normal" situation from farming. Records of foreclosure and conveyance are kept by some state departments of agriculture, but farm families can go through conveyance and foreclosure on parcels of land and not leave farming as an occupation. If farming is viewed as a career, then the termination of that career has social and economic impacts within and outside the family. Extended families may be placed in heightened stress. Banks are in danger of losing debtors and collateral. Community businesses may lose consumers, many of whom will leave bills unpaid. This indebtedness, in turn, may cause further business cutbacks and closures.

One source of data is records of bankruptcy, the end of the farm disengagement process. Farm families that filed for Chapter 7 bankruptcies were, in effect, finally leaving farming. Farmers filing for Chapter 12 protection were attempting to regain solvency within three to five years. In both cases, bankruptcy was the last option in the struggle for farm survival. Federal bankruptcy courts keep accurate records of who files for bankruptcy and to whom bankruptcy judgments are granted. From these records one can discern place of residence, type of bankruptcy and generally if the party filing for bankruptcy is a farmer or not. Unfortunately, over the years, court records changed, removing much occupational and debt structure information. But place of residence was consistent over time.

Using bankruptcy court records, the pace of the farm crisis is charted in the state of North Dakota from 1970 to $1987 .{ }^{6}$ The increasing frequency of bankruptcy is no surprise. But a trend toward "rural immiseration" and subregional differences in bankruptcy for both farm and non-farm parties is also revealed.

\section{TRENDS IN BANKRUPTCY: U.S. AND NORTH DAKOTA}

As Shepard (1984) has noted, there has been an increase in bankruptcy filings from the late 1940's through 1978. Table 1 shows the number of bankruptcies filed from 1975 to 1987 , the change from year to year, and the annual composition in terms of various chapters or types of bankruptcy.

There is a doubling of the number of bankruptcies from 1975 to 1987. Large increases were reported between 1980 and 1981 , just after the change in bankruptcy law, but 1981 was also a deep recessionary year for the entire economy. The 1985-86 increase 
reflects more accurately the level of debt found in the United States. Straight bankruptcies (Chapter 7) are more prevalent for each year than other types of bankruptcies. But over time there has been a decreasing proportion of Chapter 7 bankruptcies, a slight increase after 1980 in Chapter 11 and increases in Chapter 13 wage-earner reorganization bankruptcies.

Table 2 shows the number of bankruptcies in the Great Plains states. Texas is included because it is part of the Plains wheat growing areas, as are Oklahoma and Colorado. The table also shows the crude rate of bankruptcies per 100,000 population.

All states in the Plains show increases of 50 percent or more in the number of bankruptcies between 1977 and 1985 . The northern Plains states show a lower increase in rate, however, than do the states in the Southern Plains.

Table 3 displays the yearly frequencies of bankruptcies and farm related bankruptcies in North Dakota from 1970 to mid-1987. Between 1970 and mid-1987, almost 9,700 bankruptcies were filed in North Dakota. From 1970 to 1973, just under 1,300 bankruptcies were filed; of these, only 45 or 3.5 percent were farm related. These were the years before the large-scale Russian wheat deals and export sales. Between 1974 and 1980, there were 3,227 bankruptcies filed; of these, only 3.1 percent were farm related. But between 1981 and 1987, there were over 5100 bankruptcies filed; of these, 565 ( 11.0 percent) were farm related. While general annual increases in bankruptcies are shown, one finds level or declining bankruptcy numbers for presidential election years (except 1972). Between 1974 and 1980, there were price increases for small grains, low but escalating credit costs, spiraling land prices and an expansionist farm modernization ideology. From 1981 on, there was a sudden reversal in federal farm programs.

Table 4 shows the geographical distribution of all bankruptcies in North Dakota by substate region. State regions 1 and 8 are in the sparsely populated portion of the state. State regions 4,5 , and 7 contain Metropolitan Statistical Area counties and cities. State regions 3 and 6 are principally grain growing areas with declining towns. Considering only the three metropolitan regions (4, 5, and 7), one finds that in 1978, 69.4 percent of all bankruptcies were in those areas. By 1981, these regions produced 62.6 percent of all bankruptcies, and by 1984 these regions contained only 54.7 percent of all bankruptcies.

Table 5 presents the yearly distribution of bankruptcies by the population of places of residence for those filing.

The number of bankruptcies clearly began to increase before 1979. ${ }^{7}$ A sharp drop in the price of grain in 1977 may have had a 
Table 2. Number and Rate of Bankrupt for Great Plains States, 1976, 1979, 1983, 1985.

\begin{tabular}{|c|c|c|c|c|c|c|c|c|}
\hline \multirow[b]{2}{*}{ State } & \multicolumn{2}{|c|}{1977} & \multicolumn{2}{|c|}{1979} & \multicolumn{2}{|c|}{1983} & \multicolumn{2}{|c|}{1985} \\
\hline & $\begin{array}{c}\# \\
\text { Bank- } \\
\text { ruptcies* }\end{array}$ & $\begin{array}{c}\text { Rate Per } \\
100,000 \\
\text { Pop. }\end{array}$ & $\begin{array}{c}\# \\
\text { Bank- } \\
\text { ruptcies }\end{array}$ & $\begin{array}{c}\text { Rate Per } \\
100,000 \\
\text { Pop. }\end{array}$ & $\begin{array}{c}\# \\
\text { Bank- } \\
\text { ruptcies }\end{array}$ & $\begin{array}{c}\text { Rate Per } \\
100,000 \\
\text { Pop. }\end{array}$ & $\begin{array}{c}\# \\
\text { Bank- } \\
\text { ruptcies }\end{array}$ & $\begin{array}{c}\text { Rate Per } \\
100,000 \\
\text { Pop. } \\
\end{array}$ \\
\hline ND & 430 & 66.2 & 549 & 84.5 & 718 & 105.6 & 681 & 98.7 \\
\hline SD & 399 & 57.8 & 531 & 77.0 & 824 & 117.7 & 912 & 128.6 \\
\hline MT & 768 & 101.1 & 799 & 101.1 & 1022 & 124.6 & 1052 & 126.7 \\
\hline $\mathrm{NE}$ & 1934 & 124.8 & 2180 & 138.9 & 2290 & 143.1 & 2754 & 171.1 \\
\hline KS & 3893 & 174.6 & 3917 & 166.0 & 4298 & 176.9 & 4808 & 196.2 \\
\hline $\mathrm{CO}$ & 4041 & 153.7 & 4046 & 140.7 & 6081 & 193.0 & 1012 & 217.4 \\
\hline OK & 3915 & 138.8 & 4004 & 132.1 & 5772 & 174.9 & 7107 & 215.4 \\
\hline$T X$ & 7231 & 56.1 & 5170 & 36.3 & 12811 & 80.1 & 16836 & 102.8 \\
\hline
\end{tabular}

*Bankruptcies reported on $6 / 1$ to $6 / 30$ basis. The population estimates are taken from annual statistical abstracts. States in order are: North Dakota, South Dakota, Montana, Nebraska, Kansas, Colorado, Oklahoma, Texas.

Table 3. Frequencies on A11 Bankruptcies and Farm Related Bankruptcies in North Dakota, 1970-1987.

\begin{tabular}{|c|c|c|c|c|}
\hline Year & $\begin{array}{c}\text { Number of } \\
\text { Bankruptcies }\end{array}$ & $\begin{aligned} & \text { Change }+1 \\
& 8 \text { Over Past Year } \\
&\end{aligned}$ & $\begin{array}{c}\text { Number of Farm } \\
\text { Bankruptcies }\end{array}$ & $\begin{array}{c}\text { Change }+1 \quad- \\
8 \text { Over Past Year } \\
\end{array}$ \\
\hline 1970 & 265 & - & 10 & $\ldots$ \\
\hline 1971 & 308 & +16.28 & 9 & -10.08 \\
\hline 1972 & 348 & +13.0 & 14 & +55.6 \\
\hline 1973 & 358 & +2.9 & 12 & -14.3 \\
\hline 1974 & 317 & -11.5 & 10 & -16.7 \\
\hline 1975 & 407 & +28.4 & 11 & +10.0 \\
\hline 1976 & 419 & +2.9 & 8 & -27.3 \\
\hline 1977 & 494 & +21.4 & 22 & +175.0 \\
\hline 1978 & 502 & +1.6 & 13 & -41.0 \\
\hline 1979 & 587 & +16.9 & 25 & +92.3 \\
\hline 1980 & 551 & -6.6 & 11 & -56.0 \\
\hline 1981 & 573 & +4.0 & 36 & +227.3 \\
\hline 1982 & 710 & +23.9 & 58 & +61.1 \\
\hline 1983 & 650 & -8.5 & 87 & +50.0 \\
\hline 1984 & 650 & - - & 68 & -21.8 \\
\hline 1985 & 810 & +24.6 & 113 & +66.3 \\
\hline 1986 & 1129 & +39.4 & 105 & -7.1 \\
\hline $1987 *$ & 605 & $+7.2 *$ & 98 & +86.7 \\
\hline
\end{tabular}

$* 1 / 1$ to $6 / 30 / 87$ 
Table 4. Distribution of Bankruptcies by Households in State Regions, 1970-1984.

\begin{tabular}{|c|c|c|c|c|c|c|c|c|}
\hline Year & $\begin{array}{c}\text { NW* } \\
1 \\
\end{array}$ & $\begin{array}{c}\text { MNT } \\
2 \\
\end{array}$ & $\begin{array}{r}\mathrm{DL} \\
3 \\
\end{array}$ & $\begin{array}{c}\text { Stat } \\
\text { NE } \\
4 \\
\end{array}$ & $\begin{array}{r}\text { rons } \\
\text { SE } \\
5 \\
\end{array}$ & $\begin{array}{c}\text { JTOWN } \\
6\end{array}$ & $\begin{array}{c}\text { BIS } \\
7\end{array}$ & $\begin{array}{r}\text { SW } \\
8 \\
\end{array}$ \\
\hline 1970 & 7.98 & 14.18 & 1.98 & 11.48 & 28.18 & 7.68 & 23.28 & 5.78 \\
\hline 1971 & 2.0 & 16.0 & 4.6 & 10.1 & 36.9 & 7.5 & 17.3 & 6.5 \\
\hline i972 & 2.9 & 13.2 & 2.9 & 14.4 & 33.5 & 8.8 & 18.5 & 5.9 \\
\hline 1973 & 3.2 & 10.6 & 3.4 & 15.5 & 34.4 & 6.6 & 21.8 & 4.6 \\
\hline 1974 & 1.8 & 12.5 & 3.0 & 16.2 & 33.8 & 2.7 & 23.2 & 6.7 \\
\hline 1975 & 2.5 & 11.5 & 3.9 & 16.2 & 32.7 & 8.6 & 21.1 & 3.4 \\
\hline 1976 & 3.1 & 13.5 & 3.1 & 15.6 & 25.8 & 8.4 & 25.6 & 4.8 \\
\hline 1977 & 5.0 & 18.0 & 6.8 & 13.8 & 21.1 & 12.0 & 18.8 & 4.5 \\
\hline 1978 & 4.3 & 12.0 & 2.4 & 15.8 & 30.2 & 8.7 & 23.9 & 2.6 \\
\hline 1979 & 4.2 & 13.5 & 2.1 & 16.8 & 28.6 & 8.3 & 21.4 & 5.4 \\
\hline 1980 & 3.0 & 13.8 & 3.3 & 19.2 & 26.0 & 7.7 & 20.3 & 6.6 \\
\hline 1981 & 5.1 & 11.0 & 3.3 & 18.2 & 26.6 & 12.5 & 17.8 & 5.4 \\
\hline 1982 & 5.5 & 10.5 & 3.4 & 13.5 & 25.3 & 11.5 & 19.6 & 10.7 \\
\hline 1983 & 8.6 & 10.7 & 6.4 & 12.6 & 19.5 & 12.4 & 21.5 & 8.4 \\
\hline 1984 & 4.7 & 9.4 & 4.2 & 12.1 & 21.0 & 11,9 & 22.6 & 14.3 \\
\hline
\end{tabular}

*The state regions are: Northwest(1), Minot(2), Devils Lake(3), Northeast(4), Southeast(5), Jamestown(6), Bismark(7), Southwest(8).

Table 5. Proportions of Bankruptcies Located in Sized Places, 1970-1984

\begin{tabular}{lcccc} 
Year & \# Bankruptcies & 1,000 or Less & 1,001 to 10,000 & 10.001 or Over \\
\hline & & & & \\
1970 & 265 & 22.68 & 16.68 & 60.88 \\
1971 & 308 & 18.2 & 21.8 & 60.0 \\
1972 & 348 & 21.1 & 14.0 & 64.9 \\
1973 & 358 & 20.8 & 15.9 & 63.3 \\
1974 & 317 & 16.1 & 16.2 & 67.7 \\
1975 & 407 & 21.4 & 20.6 & 58.0 \\
1976 & 419 & 21.5 & 21.3 & 57.3 \\
1977 & 494 & 25.6 & 18.0 & 56.5 \\
1978 & 502 & 20.0 & 22.2 & 57.8 \\
1979 & 587 & 15.3 & 16.4 & 68.3 \\
1980 & 551 & 16.9 & 18.3 & 64.8 \\
1981 & & & & \\
1982 & 573 & 18.5 & 19.7 & 61.8 \\
1983 & 710 & 19.2 & 18.8 & 62.0 \\
1984 & 650 & 21.8 & 19.7 & 59.5 \\
1985 & 650 & 23.5 & 21.6 & 55.9 \\
& 810 & 24.4 & 20.3 & 55.3 \\
\hline
\end{tabular}

local impact in North Dakota, tending to drive more agribusinesses and small town merchants into bankruptcy. Over the entire period, there is a trend toward a higher proportion of bankruptcies filed from places of 10,000 people or less.

Table 6 focuses on farm-related bankruptcies per se. In the first period (1970-73), 45 percent of all farm related bankruptcies were located in the MSA state regions (Regions 4, 5, and 7). However, between 1974 and 1980, these regions produced only 34 percent of the farm related bankruptcies. In the final period $(1981-84)$ these three regions recorded 37 percent of the farm related bankruptcies. One curious jump (in State Region 1) could be attributed to energy development and the absorption of cheap agricultural labor into energy jobs. Ranchers and farmers could not afford to compete with energy salaries.

Finally, Table 7 reports the number of bankruptcies yearly, and the rate of bankruptcies per 1,000 farms. Overall the number of farms has dropped by 30 percent in the 17 year period; the number of bankruptcies has increased 1,700 percent. When standardized by the rate of bankruptcy per 1,000 farms, one can see a major jump between 1980 and 1981 , and continued high numbers through $1986^{8}$

\section{CONCLUSION}

For historians, the "agrarian transition" has been an almost linear trend, an. analog to a twilight and sunset. The discussion here has focused on the role of the fiscal crisis in farming particularly in the 1980's. As farm families leave their careers and homes, there are both social and economic implications to be considered.

It is not valid to analyze the level of farm income and government price supports and infer that the farm economy is sound, or that trends are occurring that are irreversible. Farming careers end with a formal, of ten legal finale in foreclosure or bankruptcy. These career transitions are followed by social disengagement, sometimes with feeling of shame, and altered consumption patterns because of limited incomes. There is also the depression of losing one's chosen career and experiencing concomitant status discrepancy.

The data support a thesis of "rural immiserations." Between 1970 and 1987, there was a dramatic increase in the number of farm-related bankruptcies. Data from North Dakota indicate that bankruptcies spread to non-metropolitan regions of the state. Also, higher proportions of bankruptcy filers were living in or near 
Table 6. Location of Farm Bankruptcies by State Regions, 1970-1984

\begin{tabular}{|c|c|c|c|}
\hline Region & $1970-73(N-45)$ & $1974-80(\mathrm{~N}=100)$ & $1981-84(\mathrm{~N}-239)$ \\
\hline 1 -Northwest & 48 & 138 & 38 \\
\hline 2-Minot & 13 & 16 & 15 \\
\hline 3-Devils Lake & 4 & 10 & 11 \\
\hline 4-Grand Forks & 9 & 12 & 8 \\
\hline 5 -Fargo & 20 & 7 & 15 \\
\hline 6-Souch Central & 27 & 18 & 27 \\
\hline 7-Bismarck & 16 & 15 & 15 \\
\hline 8 -Southwest & 7 & 9 & 6 \\
\hline & $\overline{1008}$ & $\frac{7}{1008}$ & $\overline{1008}$ \\
\hline
\end{tabular}

Table 7. Rates of Farm Bankruptcies per 1.000 Farms, 1970.1986

\begin{tabular}{|c|c|c|c|}
\hline Year & $\begin{array}{c}\text { \# of Farms } \\
\text { in } \\
\text { North Dakota }\end{array}$ & $\begin{array}{l}\text { \# of Farm } \\
\text { Related } \\
\text { Bankruptcies }\end{array}$ & $\begin{array}{c}\text { Bankruptcies } \\
\text { per } \\
1,000 \text { Farms } \\
\end{array}$ \\
\hline 1970 & 45,500 & 11 & .24 \\
\hline 1971 & 45,000 & 10 & .22 \\
\hline 1972 & 44,500 & 14 & .32 \\
\hline 1973 & 43,500 & 12 & .28 \\
\hline 1974 & 43,000 & 10 & .23 \\
\hline 1975 & 42,500 & 11 & .26 \\
\hline 1976 & 42,000 & 8 & .29 \\
\hline 1977 & 41,000 & 22 & .53 \\
\hline 1978 & 41,500 & 13 & .31 \\
\hline 1979 & 40,500 & 23 & .57 \\
\hline 1980 & 40,000 & 11 & .28 \\
\hline 1981 & 39,000 & 36 & .92 \\
\hline 1982 & 38,000 & 58 & 1.53 \\
\hline 1983 & 36,500 & 87 & 2.39 \\
\hline 1984 & 35,500 & 68 & 1.92 \\
\hline 1985 & 34.000 & 113 & 3.32 \\
\hline 1986 & 33,000 & 105 & 3.18 \\
\hline 1987 & 32,500 & 151. & 4.66 \\
\hline
\end{tabular}

places of 1,000 or fewer persons, and a lower proportion were living in places with populations of 10,000 and over af ter 1979.

Some implications of the fiscal crisis in farming and the agrarian transition are evident. The current fiscal crisis of farming is relatively new, perhaps starting in 1981. As more family farms filed for bankruptcy, more rural and small town businesses and their employees were drawn into the fiscal crisis and also went bankrupt. But most of the bankruptcies filed by farm families from 1979 to 1986 were either "no-asset" cases (Chapter 7), or farm business reorganizations (Chapter 11). Farmers who received these bankruptcy judgments in effect walked away from their debts and from the creditors in their community.

Families that suffered the loss of their farms were, in effect, the "walking wounded." The Heffernans (1986) noted the lingering emotional trauma as former farmers stayed behind. Rossi et al., (1983) note that younger households, not aged households, are more likely to suffer other "noxious events" such as mental depression, having children in trouble, and especially marital breakups. They found regional variation for these events (Midwest and South), but did not control for the rural and small town. In economic terms, the farmers who stay behind find shrinking employment opportunities for themselves and their spouses. They have few places to go; no career transition can be made without capital or credit. Their access to capital and credit is blocked by the stigma of bankruptcy.

The Chapter 12 legislation in late 1986 may mollify the fiscal crisis. Farmers seeking protection now are required to direct any disposable income to reduce obligations which are typically debts to local merchants. Loan renegotiations and land conveyance to lenders can be suggested by court appointed trustees. There may be an increase in farm bankruptcies between 1986 and 1993 because of the new legislation, but the negative economic impact on community businesses and agribusiness lenders should be lessened. Many farmers may work their way out of bankruptcy and back into farming. Thus, while farm bankruptcies may increase in the next five or six years, one might expect a decrease in small town business bankruptcies because of the protection given to unsecured creditors.

\section{FOOTNOTES}

1. In an insightful article on farm bankruptcies from 1910 to 1978 , Shepard and Collins (1982) noted that since World War II 
increasing farm size tended to coincide with heightened vulnerability to bankruptcy. High levels of debt financing per se were not associated with increased incidences of farm bankruptcy.

2. The choice of analysis of the fiscal crisis is deliberate. Crop failures are not a problem. Marketing and cash flow problems are more central. Federal farm policy to date has poured bellows of dollars into farm income. As Shepard and Collins (1982:614) point out: ". . There is no evidence that agricultural support payments have induced, deferred or reduced farm failures." The changed role of the federal government in export policy has not been analyzed as a source of farm failure. Our belief is that erratic changes in policy and lack of long-term planning by federal policymakers influence farm failures (see Mooney, 1986; Campbell et al., 1984).

3. Alston noted that between 1920 and 1940 the yearly average for farm loss was 96,000 farms in the U.S.

4. White (1980) noted that the role of trustee became more difficult after 1979. Secured claims from government agencies (e.g. taxes, and credits from FmHA and FLB) came first. But unsecured debtors fought for the "me-first" position. In addition, under Chapter 12 legislation, a court-appointed trustee would need to be able to run a farm.

5. This sequence is suggested by Shepard and Collins (1982) to explain farm failures from 1946-1978.

6. North Dakota differs from the remaining Plains states in two key areas. First, it has a state owned bank which cooperated in funding beginning farmer loans at lower interest rates in the early 1980's. Second, the state department of agriculture initiated a farm credit counseling program (1984) and a farm credit review board for loan renegotiation in 1985 .

7. This is contrary to Shepard's research (1984) that bankruptcy filings increased after passage of the more lenient Bankruptcy Act of 1979 .

8. Shepard and Collins (1982) noted a rate of 38.2 bankruptcies per 100,000 farms in 1976. The North Dakota rate per 100,000 farms for 1978 is 31.3 , slightly below the national average.

\section{REFERENCES}

Ahalt, I.M., and R.A. Murray

1956 How Young Farmers Become Established. Miscellaneous publication No. 271. College Park, MD: Department of Agricultural Education, University of Maryland.

Alston, L.J.

1983 "Farm Foreclosure in the U.S. During the Inter-War Period." Journal of Economic History 43:883-903.

Arnold, Lester L.

1957 Accumulation in Getting Started Farming. Bulletin 638. Agricultural Experiment Station. West Lafayette, IN: Purdue University.

Buttel, Frederick H. and William L. Flinn

1975 "Sources and Consequences of Agrarian Values in American Society." Rural Sociology 40 (Summer):134-151.

Campbell, Rex R., W.D. Heffernan and J.C. Gilles

1984 "Farm Operator Cycles and Farm Debts: An Accident of Timing." Rural Sociologist 4:405-7.

Coffman, George W.

1979 "Entry and Exits: Barriers and Incentives." In Structure Issues of American Agriculture, USDA-ESCS Agricultural Economics Report 438, Washington, DC: U.S. Government Printing Office.

Coughenour, Milton and Gregory Kowalski

1977 "Status and Role of Fathers and Sons on Partnership Farms." Rural Sociology 42 (Summer):181-205.

Danbom, David B.

1979 The Resisted Revolution: Urban America and the Industrialization of Agriculture, 1900-1930. Ames, IA: The Iowa State University Press.

Dye, R.A.

1986 "An Economic Analysis of Bankruptcy Statutes." Economic Inquiry 24:417-28

Fite, Gilbert C.

1984 Cotton Fields No More: Southern Agriculture, 1865-1980. Lexington, KY: The University of Kentucky Press.

Flinn, William L. and Donald E. Johnson

1974 "Agrarianism Among Wisconsin Farmers." Rural Sociology 39 (Summer):187-204. 
Hammig, Michael

1986 "A Financial Management Profile of South Carolina Agriculture." In Proceedings of the Regional Workshop on the Food Security Act of 1985. Mississippi State, MS: Southern Rural Development Center.

Heffernan, William B. and Judith B. Heffernan

1986 "Impact of the Farm Crisis on Rural Families and Communities." The Rural Sociologist 6 (3):160-170.

Hottel, J.B. and P.J. Barry

1978 "Issues Related to Entry of Young People Into Farming." Agricultural Finance Review 38:8-13.

Martinson, Virgil O.

1970 "Similarities and Differences Between Youth Who Have Become Established in or Have Discontinued Farming." Unpublished Ph.D. thesis. Madison, WI: University of Wisconsin-Madison.

Melichar, Emmanuel

1984 "A Financial Perspective on Agriculture." Federal Reserve Bulletin 70 (1):1-14.

Mooney, Patrick H.

1986 "The Political Economy of Credit in American Agriculture." Rural Sociology 51 (4):449-70.

Rogers, S.C. and S. Salamon

1983 "Inheritance and Social Organization Among Family Farms." American Ethnologist 10:529-50.

Rohrer, Wayne C. and Leonard H. Douglas

1969 The Agrarian Transition: Dualism and Change. New York: Bobbs-Merrill Inc.

Rosenblatt, Paul C. and L.O. Keller

1983 "Economic Vulnerability and Economic Stress in Farm Couples." Family Relations 32 (October):567-73 .

Rossi, Peter, James Wright, Eleanor Weber-Burden, and Joseph

Pereira

1983 Victims of the Environment. New York: Plenum Press.

Salamon, Sonya and Shirley M. O'Reilly

1979 "Family Land and Developmental Cycles Among Illinois Farmers." Rural Sociology 44:525-42.

Salamon, Sonya

1985 "Ethnic Communities and the Structure of Agriculture." Rural Sociology 50 (3):323-40.

Shepard, Lawrence

1984 "Personal Failures and the Bankruptcy Reform Act of 1978." Journal of Law and Economics 27 (October):419437.
Shepard, L.E. and R.A. Collins

1982 "Why do Farmers Fail? Farm Bankruptcies 1910-78." Shover, John American Journal of Agricultural Economics 64 (4):609-615.

1965 Cornbelt Rebellion: The Farmers Holiday Association. Urbana, IL: The University of Illinois Press.

1976 First Majority-Last Minority: The Transforming of Rural Life in America. DeKalb, IL: Northern Illinois University Press.

Smith, John P. and G.V. Cole

1981 "Correlates of Attitudes Toward Farming for Beginning Farmers: The Effect of Social Structure." Paper presented at the annual meeting of the Rural Sociological Society, Guelph, Ontario.

Smith, John P., Jeffrey S. Weispfenning and William D. Heffernan

1984 "Farm Credit Counseling During the Financial Crisis." The Rural Sociologist 4 (6):409-10.

Synar, Michael

1986 Memorandum re: Report on Farm Bankruptcy Personal letter. Washington, DC: U.S. House of Representatives.

United States Department of Agriculture

1985 Fact Book of U.S. Agriculture. Miscellaneous publication No. 1063. Washington, DC: U.S. Government Printing Office.

Webb, D.C.

1983 "Contingent Claims, Personal Loans and the Irrelevance of Corporate Financial Structure." Economics Journal 93:832-46.

White, M.J.

1980 "Public Policy Toward Bankruptcy: Me-First and Other Priority Rules." Bell Journal of Economics 11:550-64.

Wilkenning, Eugene A.

1981 "Work Roles, Decision-making and Satisfaction of Farm Husbands and Wives in Wisconsin, 1962 and 1979." Research Report 3147, College of Agriculture and Life Science. Madison, WI: University of Wisconsin-Madison.

Wright, Carl E.

1943 "Occupational Distribution Entrance into Farming of Former Students of Vocational Agriculture." Ph.D. thesis. Department of Rural Sociology, Cornell University, Ithaca, NY. 